\title{
The Existential Experiences of Double-Minority Talents in Post 2017's Governor Election: A Phenomenological Study
}

\author{
Saragih Denni Boy ${ }^{1 *}$, Winoto Hery ${ }^{2}$, Mokorowu Yanny $^{1}$, and Peranginangin Prasasti $^{1}$ \\ ${ }^{1}$ Ukrida Center of Character Development, Ukrida, Jl. Tanjung Duren Raya No.4, \\ Jakarta Barat 11470, Indonesia \\ ${ }^{2}$ Faculty of Economics, Ukrida, Jl. Tanjung Duren Raya No.4 Jakarta Barat 11470, Indonesia
}

\begin{abstract}
The political career of Basuki Tjahaya Purnama (BTP) affects various groups of people in different ways. One of the groups that were deeply affected by the series of events before and after 2017's Jakarta Governor election are double minorities talents who aspire to contribute to Indonesia inspired by BTP's leadership. This paper explores the experience of specific group of double minority talents in the aftermath of political turbulence in Jakarta. The qualitative findings show that many talents were affected by the situation in relation to their aspiration to contribute, their decision to stay in Indonesia and their thinking about the future of Chinese-Christian talents in Indonesia. In the long run the situation and similar incidents may result in the loss of talents leaving Indonesia for other countries.
\end{abstract}

Keywords: Minorities, Chinese-Christian, participation, phenomenology, talents, human-capital.

\section{Introduction}

Basuki Tjahaya Purnama (BTP) attracted many talents to work as his aides during his term as Jakarta's governor. Many graduates from top universities in Asia, UK, Australia and US were willing to spend a period of time, thus halting their career for a while, to work with him as an aide. One study shows that returning overseas graduates are important human capital in the global scene [1]. Another study show that they also impact political scene in a country [2]. These talents bring with them precious human-capital in term of knowledge, technology and global experiences. Their contributions for the development of Indonesia cannot be overrated. Thus it is a significant phenomenon that many such talents come in a substantial number to volunteer in Jakarta Governor Office.

Among the talents, many have the background of "double-minorities," a term that is not officially used in Indonesia but reflect the socio-cultural experience of Chinese-Christians in Indonesia. In a way their participation in BTP's office is a sign of moving beyond ambivalence of identity toward full participation in Indonesia's social-political scene [3]. BTP as a "double-minority," with his strong leadership and the public perception of his

* Corresponding author: denni.boy@ukrida.ac.id 
integrity, serves as a model that such participation is a real possibility in the new Reformed Indonesia Order [4].

However this development was interrupted by the political scenes of Jakarta Governor Election 2017 where BTP loss the election and the court's sentence against BTP on allegation of religious blasphemy. These two incidents affect profoundly his supporters and impact deeply the experience of double-minorities in Indonesia. Particularly so because the issues of ethnic and religious identity shadowed the process of Jakarta's election and the justice of the court [5]. The social-political tension during and following the events was the high point in Jakarta's sociological scene 2017 and the experience of double-minorities in general.

This paper is an exploration of existential experience of double-minorities talents in the aftermath of these two incidents. Using qualitative interview, the research shows that the events affects them in three important areas namely their aspiration to contribute, their decision to stay or leave the country and their attitude toward the future of ChineseChristian in Indonesia. The paper begins with the design of the research, the findings and discussion, and finally the conclusion of the research.

\section{Research details}

The research is conducted to twelve select individuals. However because the nature and the sensitivity of the research only six respondents were willing to give consent for their answers to be published. As such, this paper will be based only from the six interviews. Double minorities in this paper is defined specifically as Chinese-Christian background. Four of the respondent are age $25 \mathrm{yr}$ old to $30 \mathrm{yr}$ old, two are in early 30 . Talent is referred to under 40 adult who studied overseas and has aspiration to participate in Indonesia development through working in various sectors in Indonesia, specifically in relation to democracy, government, politics and social works. The term talent is used because the participants are chosen from graduates of top universities in Asia, Australia, US and UK. They are considered talent from a human capital point of view. Since the nature of the questions are very sensitive, no name is presented, and only general background of respondent is introduced. Some of the respondents spent several months to work with BTP as his aides, in this particular case, the paper will not disclose their university's background. The interviews are conducted with open questions about their existential experience, the strongest feelings they underwent and the effect of the experience toward their participation to Indonesia society [6].

\section{Results and discussion}

All participants of the research have high regard to BTP's character as a leader. One of the respondents who spent a period of time as an aide in Governor Office provide the following description of BTP as a leader.

"BTP is genuine, sincere, hardworking, and compassionate. He's one of the most inspiring leaders that I've come across. He's willing to 'sacrifice' his personal and alternative professional lives for Jakarta, without expecting anything in return. He has his agenda set on only the right and good things for the city and country, and nothing is for his own personal agenda. He's not afraid to go against stereotypes or bureaucracy when he sees something wrong, and correct them. Even though he can seem to be 'fierce' or 'aggressive' sometimes, his heart is kind and he does everything for his fellow Indonesians."

Most of the respondents see the connection between BTP's faith and his character and integrity, including his style of leadership. However his background as a Chinese-Christian 
is an important element in their perception of BTP's identity. One of the respondent remarks,

"That he bothered to join politics in the first place has inspired me. This is pretty

rare for Indonesian Chinese. We were taught to "know our place", and that place

excludes politics."

The responses of the respondent show that none of them see BTP's loss was fair and square as the result of a good democratic process. All see that religious-blasphemy case that was played-out in the media during the campaign significantly swung the result of the election. With the high satisfaction index of Jakarta's citizen (70\%) during his leadership, none of the respondents anticipated the loss. One respondent who works as a researcher in a top overseas university and who plans to return to Indonesia to be a lecturer provide the following comment.

"BTP was loss because of Al-Maidah scandal. Even without the scandal, BTP would

be smeared by religion-based campaign anyway. If Jokowi who is legitimate

Moslem was attacked with religion-based issues, then surely BTP, who is not a

Muslim, will. But the scandal "justified" such approaches by his opponents."

In relation to the court sentence, none of the respondents see it as an expression of the court's justice. Most see that BTP was sacrificed for "greater good," and one respondent said that "the court was afraid of the mass and threatened by BTP's opponents." Particularly in relation to material subject of the case, one respondent remarks,

"The sentence is to appease the hardliners. Having said that, what's actually more problematic and should be challenged in constitutional court is the existence of law on religious blasphemy in itself."

The strongest feelings that they underwent when BTP lose the election were sad (three respondents), disappointed (two respondents) and pity (one respondent). Other feelings were angry, hopelessness and helplessness. One respondent remarks, "It is the way it is, we can't do anything." Strongest and more intense feelings were experienced following the court's sentence. Different intense words were chosen to express the feeling. One respondent said that he felt outrage of justice. Others were sad, shocked and angry.

However the responses toward Indonesia as a country are mixed. Some become pessimistic about contributing to Indonesia. One respondent who studied in a top university in Singapore and returned to Indonesia to start a business remarks,

"The event lead me to lose hope on Indonesia's future. Because they simply show that despite there are people who want this country to progress, the powerful people still think of themselves and do not care about the country and the people."

Another respondent who previously work abroad and started a career in Indonesia responded with similar pessimism. She remarks,

"Looking at a very good leader who has contributed a lot to Indonesia was treated unfairly, I was thinking why should I contribute? If I decided to contribute, how can my contribution bring impact to this country? Looking at the fact that BTP has contributed so much but yet some people just did not change and some people still tried to trap him."

But there are respondents who are reflecting about their attitude toward politics and that the events should be an opportunity to reevaluate the genuineness of their participation in Indonesia's politics and nation building. One of the respondent remarks,

"I felt that the events did expose some hypocrisy and tribalism among Chinese-

Christians in Indonesia. As I mentioned earlier, in general Indonesian Chinese didn't really bother participating in politics. We "know our place". And then suddenly we showed our enthusiasm in politics, just because of BTP. I think Chinese-Christians should reflect on this. If we go back to our previous ways before BTP, then we will be found hypocrites indeed." 
Their plan about staying or leaving Indonesia is also a mixed response. Some are thinking of finding another country to live until Indonesia ready for their contribution. One respondent said that, "It is better to use the talent in some other place where they can appreciate the contribution better." One respondent reported about general responses as mixed.

"I've seen mixed responses. Some still believe there is still hope for Indonesia, and want to contribute. Bu others gave up and probably refrain from going back to Indonesia."

But there are some respondents that reacted in more positive way, believing that somehow Chinese-Christian will grow from ethnic-centered community into a social-politically involved community based on a genuine care for society [7]. This means that they must learn to participate not only because BTP represent their identity but because they share the same concern for Indonesia that BTP has. One of the response remark the following.

"I see that the response of double minorities talents are mainly negative and disheartened, but I did saw some who were inspired and challenged even further to continue his legacy as the trailblazer. But, again, if we followed politics just because of BTP, then we actually are no different from and as tribalistic as those who we 'despised'."

The qualitative findings show that the talents identify themselves deeply and personally with the political career of BTP, and the response to BTP's contribution is a test case for the future of Chinese-Christian in Indonesia [8]. In the global scene where the appreciation of one's talent know no political boundary, the fate of BTP will affect the future contribution of talents who identify themselves with BTP. However this is not the end of the story since BTP's political career may continue after his release from the jail. The research show that BTP, and similar figures, may attract talents from abroad to contribute for Indonesia. In the past figures like physicist Johannes Surya, who also a ChineseChristian, has served as a magnet that attracted many talents to return as academics in Indonesia. President Joko Widodo is also another good magnet for such talents to consider returning to Indonesia. The loss of human capital following the events surrounding BTP's case could be significant. This needs another research that explores its quantitative loss. But the gain in human capital may also improve in the future depending on the perception of justice, acceptance and fairness that provide a space for talents to contribute to the development of Indonesia [9, 10].

\section{Conclusion}

This study shows that the loss of BTP and the court's sentence of religious blasphemy intensely impact a segment of society, namely double-minorities talents which share similar ethnic-religious background with BTP. The aspiration to contribute is greatly improved based of role-model shown by BTP. The failure of BTP to secure a second term and the sociological situation that accompanied it, on the other hand, challenge whether such aspiration will be welcomed. The events are also affecting their thinking about staying in Indonesia. With their background as graduates of top universities, the migration is a real possibility and may result in the loss of human capital for Indonesia. And finally, the events are also a test case for the possibility of Chinese-Christian's participation in Indonesia's politics. It is a mixed response however in relation to this aspect. While many responded negatively, some see this as a good lesson that challenge Chinese-Christian to find their political motif not in a certain person but in a true and real concern for the country. 


\section{References}

1. D. Zweig, C. Changgui, S. Rosen, China Q., 179:735-757(2004). https://www.jstor.org/stable/20192378

2. H. Li, Asian Perspective, 30:5-29(2006). https://www.jstor.org/stable/42704542

3. I. Ang, Trapped in ambivalence: Chinese Indonesian, victimhood and the debris of history, In: Race "Panics" and The Memory of Migration, M. Morris, B. de Bary (Eds.), Hong Kong: University Press (2001). https://researchdirect.westernsydney.edu.au/islandora/object/uws:2110/

4. B.T. Purnama, The Story of Basuki Tjahaja Purnama. Jakarta: Center for Democracy and Tranparency (2008). [in Bahasa Indonesia]. https://books.google.co.id/books/about/Merubah_Indonesia.html?hl=id\&id=jJEMAQA AMAAJ\&redir_esc $=y$

5. M.G. Tan, A. Dahana, The ethnic Chinese in Indonesia: Issues of identity. In: Ethnic Chinese as Southeast Asians, L. Suryadinata (Eds) New York: Palgrave Macmillan, (1997), p.33-71.

https://link.springer.com/chapter/10.1007/978-1-137-07635-9_2

6. D. Langdridge, Phenomenological Psychology: Theory, Research and Method, London: Pearson (2007). http://oro.open.ac.uk/8332/

7. T. Yen-Ling, Indonesia, 92:125-155(2001). https://www.jstor.org/stable/10.5728/indonesia.92.0125

8. A.L. Freedman, Political participation and ethnic minorities, Chinese Overseas in Malaysia, Indonesia and the United States. New York: Rouledge (2010). https://www.researchgate.net/publication/249015331_Political_Institutions_and_Ethnic Chinese Identity in Indonesia

9. I. Rae, M. Witzel, The Overseas Chinese of South East Asia. New York: Palgrave Macmillan (2008). https://www.palgrave.com/gp/book/9781403991652

10. S.W. Sai, C.Y., Hoon, Chinese Indonesia Reassesed. New York: Rouledge (2012). https://www.taylorfrancis.com/books/9780203095362 